\title{
Environmental Applications of Supermacroporous Cryogels
}

\author{
Müge Andaç \\ Environmental Engineering Department \\ Hacettepe University \\ 06800, Beytepe, Ankara, Turkey \\ andac@hacettepe.edu.tr
}

Hydrogels, which are synthesized at subzero temperatures, can be named as cryogels. These materials are fabricated in a frozen state when the ice crystals serve as porogens, and a network of inter-connected pores is formed after the ice crystals melted. In contrast to hydrogels, cryogels have large pore size $(\mathrm{d}>1 \mu \mathrm{m})$, short diffusion path, good biocompatibility, and high mechanical strength [1]. They could widely be used as scaffolds in tissue engineering [2], and as separation matrices in chromatography [3]. They can be either used as pure polymeric or filled with solid micro/nano-particles in literature for environmental applications [4-6]. To a large extent, the applications of cryogels are defined by their macroporous structure allowing effective mass transport of solutes, good mechanical properties and water state in the interior of these highly hydrated systems similar to the state of bulk water. A supermacroporous cryogel is a good alternative to traditional separation and removal matrices having the advantages as large pores, short diffusion path, low-pressure drop, and very short residence times for both adsorption and elution.

In this presentation, general aspects of supermacroporous cryogels are described and particularly their use in environmental applications are introduced. Some important keynotes are discussed in terms of target molecule and functional monomer interactions. Among these, different forms of cryogels are also introduced for further knowledge in environmental science and nanotechnology.

\section{References}

[1] B. Mattiasson, A. Kumar, I. Yu Galaev, Eds. Macroporous Polymers. Production Properties and Biotechnological/Biomedical Applications. CRC Press, 2009.

[2]. M. Andac, F. M. Plieva, A. Denizli,I. Yu Galaev, B. Mattiasson, "Poly(hydroxyethyl methacrylate)-Based Macroporous Hydrogels with Disulfide Cross-Linker", Macromol. Chem. Phys, vol. 209, pp. 577-584, 2008.

[3]. N. Bereli, M. Andaç, G. Baydemir, R. Say, I. Y. Galaev, A. Denizli, "Protein recognition via ion-coordinated molecularly imprinted supermacroporous cryogels", J. Chromatogr. A, vol. 1190, pp. 18, 2008.

[4]. I. N. Savina, C. J. English, R. L. D. Whitby, Y. Zheng, A. Leistner,S. V. Mikhalovsky, A. B.Cundy, "High efficiency removal of dissolved As(III) using iron nanoparticle-embedded macroporous polymer composites", Journal of Hazardous Materials, vol. 192, pp. 1002-1008, 2011.

[5]. M. Le Noir, F. M. Plieva, T. Hey, B. Guieyse, B. Mattiasson, "Macroporous molecularly imprinted polymer/cryogel composite systems for the removal of endocrine disrupting trace contaminants", J. Chromatogr. A, vol. 1154, pp. 158$164,2007$.

[6]. E. Tamahkar, M. Bakhshpour, M. Andaç, A. Denizli. "Ni(II)-imprinted cryogels for selective removal of nickel ions from aqueous solutions." Sep. Purif. Technol., vol. 179, pp. 36-44, 2017. 